\title{
ОСОБЛИВОСТІ ПРОКСИМАЛЬНОГО І ДИСТАЛЬНОГО ТРАНСПОРТУ НАТРІЮ ЗА УМОВ ГОСТРОЇ КРОВОВТРАТИ, УСКЛАДНЕНОЇ ІШЕМІЄЮ-РЕПЕРФУЗІЄЮ КІНЦІВКИ, ТА ЇХ КОРЕКЦІЯ В ЕКСПЕРИМЕНТІ
}

Вступ. Найефективнішим способом зупинки масивної зовнішньої кровотечі визнано накладання джгута. Повне знекровлення кінцівки протягом 2 год може зумовити ушкодження нервів і судин під джгутом, міонекроз, рабдоміоліз, тромбоз глибоких вен. Однак недостатньо вивчено роль ішемії-реперфрузії кінцівки в патогенезі порушень іонорегулювальної функції нирок за умов гострої крововтрати. Немає даних щодо есрективності їх корекції карбацетамом.

Мета дослідження - 3'ясувати особливості ниркового транспорту натрію в ранній період після нанесення скелетної травми різної тяжкості, ускладненої крововтратою, та ефективність корекції виявлених порушень карбацетамом.

Методи дослідження. Експерименти виконано на 108-ми нелінійних щурах-самцях масою 160-180 г. У 1-й дослідній групі моделювали двогодинну ішемію кінцівки з наступною реперорузією, у 2-й - гостру крововтрату в обсязі 20-22 \% об'єму циркулюючої крові, у 3-й - ці ушкодження поєднували, у 4-й - тваринам з гострою крововтратою та ішемією-реперфузією кінцівки внутрішньочеревно вводили карбацетам у дозі 5 мг/ке. Через 1 і 2 год, а також через 1, 7 та 14 діб у щурів дослідних груп визначали фрункціональний стан нирок методом водного навантаження. Тварин контрольної групи вводили в наркоз і брали для досліджень через 1 год. Визначали діурез та концентрацію іонів натрію в сечі й сироватці крові. Розраховували проксимальний і дистальний транспорт натрію.

Результати й обговорення. Реперфузія після двогодинної ішемії кінцівки в білих щурів супроводжувалась істотним зниженням проксимального і дистального транспорту натрію з максимумом порушень через 1 добу та нормалізацією показників через 14 діб. Гостра крововтрата суттєво поглиблювала порушення процесів проксимального і дистального транспорту натрію. Поєднання гострої крововтрати та ішемії-реперфузії кінцівки супроводжувалось більшим зниженням показників. Використання карбацетаму привело до покращення досліджуваних показників через 7 і 14 діб застосування, які не досягали рівня контрольної групи.

Висновки. Ускладнення гострої крововтрати двогодинною ішемією та реперфузією кінцівки викликає більше зниження величини проксимального і дистального транспорту натрію порівняно з іншими дослідними групами. Застосування за цих умов карбацетаму супроводжується нефропротекторним ефректом.

КЛЮЧОВІ СЛОВА: крововтрата; ішемія-реперфузія кінцівки; нирка; проксимальний і дистальний транспорт натрію.

ВСТУП. Зростання частоти терористичних атак і локальних збройних конорліктів належить до актуальних проблем сьогодення [1]. За цих умов відмічають значну частоту гострої крововтрати, яка у 80-90 \% випадків є основною причиною загибелі постраждалих і поранених [2]. Найефективнішим способом зупинки масивної зовнішньої кровотечі визнано накладання джгута, який повністю припиняє артеріальний кровотік [3].

У роботах окремих авторів відзначено, що повне знекровлення кінцівки протягом 2 год може зумовити ушкодження нервів і судин під джгутом, (с) В. В. Шацький, 2019 міонекроз, рабдоміоліз, тромбоз глибоких вен [4]. Однак ще більші порушення в органах та м'яких тканинах кінцівки настають після її реперфрузії $[5,6]$. У м'язовій тканині суттєво активуються процеси ліпідної пероксидації, посилюється деструкція клітинних мембран, що викликає запалення індукованих ішемією локальних ділянок. Медіатори запалення та токсичні метаболіти надходять у системний кровотік і можуть негативно впливати на життєво важливі органи [7]. Доведено, що реперфузія кінцівки після двогодинної ішемії на тлі закритої травми органів черевної порожнини та крововтрати здатна поглиблювати прояви поліорганної недостатності 
$[8,9]$. Однак недостатньо вивченою продовжує залишатися роль ішемії-реперфузії кінцівки в патогенезі порушень іонорегулювальної фрункції нирок за умов гострої крововтрати. Немає даних щодо ефективності їх корекції карбацетамом, який при скелетній травмі, ускладненій крововтратою, проявляє антиоксидантну, імуномодулюючу, детоксикуючу, мембраностабілізуючу і тканинопротекторну дію [10].

Мета дослідження - з'ясувати особливості ниркового транспорту іонів натрію в ранній період після нанесення скелетної травми різної тяжкості, ускладненої крововтратою, та ефективність корекції виявлених порушень карбацетамом.

МЕТОДИ ДОСЛІДЖЕННЯ. Експерименти виконано на 108-ми нелінійних щурах-самцях масою 160-180 г з дотриманням правил Європейської конвенції про захист хребетних тварин, що використовуються для дослідних та інших наукових цілей (Страсбург, 1986).

Усіх тварин поділили на п'ять груп: контрольну та чотири дослідних (по 6 щурів у кожній). До 1-ї дослідної групи ввійшли тварини, яким моделювали ішемію-реперфузію кінцівки. Під тіопентал-натрієвим знеболюванням (40 мг.к $\Gamma^{-1}$ маси тіла) проксимально на ліву лапку щурів на 120 хв накладали джгут. Застосовували смужку еластичного джгута "SWAT-T" (США) шириною 10 мм, що відповідає ширині джгута при накладанні на стегно дорослої людини. Джгут затягували відповідно до нанесеного на нього індикатора есрективного тиску, який припиняє кровотік, що додатково було підтверджено реографічним методом. Тваринам 2-ї дослідної групи за умов знеболювання моделювали гостру крововтрату шляхом пересікання стегнової вени. Після досягнення обсягу крововтрати 20-22 \% об'єму циркулюючої крові щурам забезпечували гемостаз. У 3-й дослідній групі ці ушкодження поєднували. Тваринам 3 гострою крововтратою, ускладненою ішемією-реперфузією кінцівки, які входили до 4-ї дослідної групи, з метою корекції внутрішньочеревно вводили карбацетам (Інститут фрізико-органічної хімії та вуглехімії $\mathrm{HAH}$ України, Донецьк) у дозі 5 мг на кілограм маси щура [10]. Щурів контрольної групи вводили в наркоз, застосовуючи еквівалентну дозу тіопентал-натрію, накладали джгут на 2 год без припинення кровотоку і в подальшому брали для досліджень через 1 год.

Через 1 і 2 год, а також через 1, 7 та 14 діб у піддослідних тварин визначали фуннціональний стан нирок методом водного навантаження [11]. Через металевий зонд у шлунок вводили підігріту до $30^{\circ} \mathrm{C}$ водогінну воду в об'ємі 5 \% від маси тіла щура. Сечу збирали протягом 2 год і визначали діурез. Після забору сечі під тіопентал-натрієвим знеболюванням щурів виводили з експерименту методом тотального кровопускання із серця, що в ранній період експерименту відповідало 3 і 4 год реперфузії. У сечі й сироватці крові визначали концентрацію натрію унісрікованим методом для аналізатора біохімічного "Humalazer 2000". Розраховували величини проксимального і дистального транспорту натрію [11].

Вірогідність відмінностей між контрольною і дослідними групами оцінювали з використанням непараметричного критерію Манна - Уїтні. Відмінності вважали істинними при вірогідності нульової гіпотези менше 5 \% $(p<0,05)$.

РЕЗУЛЬТАТИ Й ОБГОВОРЕННЯ. ДОсЛіДЖеНня показали (табл. 1), що за умов моделювання ішемії-реперфузії проксимальний транспорт натрію до 7 доби реперфузійного періоду був істотно меншим, ніж у контрольній групі, досягаючи мінімальної величини через 1 добу (на $46,7 \%, p<0,05)$. Через 14 діб він повертався до рівня контрольної групи $(p>0,05)$ й суттєво перевищував показник на 4 год, 1 і 7 доби $(p<0,05)$. Моделювання гострої крововтрати зумовило статистично значуще зниження проксимального транспорту натрію порівняно з контролем у всі терміни спостереження 3 мінімумом теж через 1 добу реперфрузійного періоду (на 71,6 \%, p<0,05). Найбільші порушення досліджуваного показника виникали після моделювання гострої крововтрати та її ускладнення ішемією-реперфузією кінцівки. За цих умов величина показника через 4 год та 1 добу виявилася істотно меншою порівняно з групою, в якій моделювали саму гостру крововтрату $\left(\mathrm{p}_{1-3}<0,05\right)$.

У свою чергу, дистальний транспорт натрію (табл. 2) під впливом ішемії-реперфузії кінцівки теж знижувався порівняно з контролем, проте результат виявився статистично значущим лише через 4 год, 1 і 7 діб реперфузійного періоду $(p<0,05)$. За цих умов показник досягав мінімуму через 1 добу і був на 20,0 \% меншим від контролю $(p<0,05)$. Моделювання гострої крововтрати зумовило статистично вірогідне зниження дистального транспорту натрію порівняно з контролем у всі терміни спостереження $(\mathrm{p}<0,05)$. Показник досягав мінімуму через 1 добу (на 47,8 \% був меншим від контролю, p<0,05), в подальшому зростав і через 14 діб істотно перевищував усі попередні терміни спостереження $(p<0,05)$. Ускладнення гострої крововтрати ішемією-реперфрузією кінцівки викликало ще більше зниження дистального транспорту натрію, що було статистично вірогідним порівняно з контролем у 
Таблиця 1 - Проксимальний транспорт натрію (мкмоль: $\mathbf{X B}^{-1}$ ) 3 розрахунку на 100 г маси тварини після гострої крововтрати, ускладненої ішемією-реперфузією кінцівки (Me (LQ; UQ) - медіана (нижній і верхній квартилі))

\begin{tabular}{|c|c|c|c|c|c|}
\hline \multirow{2}{*}{ Дослідна група } & \multicolumn{5}{|c|}{ Термін реперфузійного періоду } \\
\hline & 3 год & 4 год & 1 доба & 7 доба & 14 доба \\
\hline \multicolumn{6}{|c|}{ Контрольна група=53,15 $(50,01 ; 56,48)(n=6)$} \\
\hline $\begin{array}{l}\text { 1-ша група } \\
\text { (ішемія-реперфузія) }\end{array}$ & $\begin{array}{c}44,95^{\star} \\
(43,31 ; 46,89) \\
(n=6)\end{array}$ & $\begin{array}{c}42,37^{*} \\
(41,35 ; 44,16) \\
(n=6)\end{array}$ & $\begin{array}{c}28,34^{* 3 r, 4 \Gamma} \\
(27,94 ; 29,50) \\
(n=6)\end{array}$ & $\begin{array}{c}38,25^{\star 1 д} \\
(34,84 ; 43,48) \\
(n=6)\end{array}$ & $\begin{array}{c}52,43^{4,, 1 A, 7 \AA} \\
(49,72 ; 57,57) \\
(n=6)\end{array}$ \\
\hline $\begin{array}{l}\text { 2-га група } \\
\text { (крововтрата) }\end{array}$ & $\begin{array}{c}28,93^{\star} \\
(25,87 ; 30,43) \\
(n=6)\end{array}$ & $\begin{array}{c}25,22^{\star} \\
(21,33 ; 28,16) \\
(n=6)\end{array}$ & $\begin{array}{c}15,08 * 3 r, 4 r \\
(14,66 ; 16,40) \\
(n=6)\end{array}$ & $\begin{array}{c}20,60 * 3,1 \mathrm{~A} \\
(18,71 ; 22,03) \\
(\mathrm{n}=6)\end{array}$ & $\begin{array}{c}23,12^{\star 1 A} \\
(19,26 ; 30,64) \\
(n=6)\end{array}$ \\
\hline $\begin{array}{l}\text { 3-тя група } \\
\text { (ішемія-реперфрузія+ } \\
\text { крововтрата) }\end{array}$ & $\begin{array}{c}24,30 * \\
(22,40 ; 25,42) \\
(n=6)\end{array}$ & $\begin{array}{c}18,49 * 35 \\
(17,00 ; 19,06) \\
(n=6)\end{array}$ & $\begin{array}{c}11,89 * 3 r, 4 r \\
(10,93 ; 13,11) \\
(n=6)\end{array}$ & $\begin{array}{c}14,05^{\star 3 r, 4 r} \\
(12,82 ; 15,48) \\
(n=6)\end{array}$ & $\begin{array}{c}18,23^{* 3 r, 1 A, 7 \AA} \\
(15,00 ; 20,29) \\
(n=6)\end{array}$ \\
\hline $\mathrm{p}_{1-2}$ & $<0,05$ & $<0,05$ & $<0,05$ & $<0,05$ & $<0,05$ \\
\hline$p_{1-3}$ & $<0,05$ & $<0,05$ & $<0,05$ & $<0,05$ & $<0,05$ \\
\hline$p_{2-3}$ & $>0,05$ & $<0,05$ & $>0,05$ & $<0,05$ & $>0,05$ \\
\hline
\end{tabular}

Примітки. Тут і в таблиці 2:

1. * - відмінності стосовно контрольної групи статистично вірогідні $(p<0,05)$.

2. $\mathrm{p}_{1-2}$ - вірогідність відмінностей між 1-ю і 2-ю дослідними групами.

3. $\mathrm{p}_{1-3}$ - вірогідність відмінностей між 1-ю і 2-ю дослідними групами.

4. $\mathrm{p}_{2-3}$ - вірогідність відмінностей між 1-ю і 3-ю дослідними групами.

5. зг,4,1,7,7д- відмінності стосовно, відповідно, 3 і 4 год, а також 1 та 7 діб експерименту статистично вірогідні $(p<0,05)$.

Таблиця 2 - Дистальний транспорт натрію (мкмоль.2 год-1) 3 розрахунку на 100 г маси тварини після гострої крововтрати, ускладненої ішемією-реперфузією кінцівки

(Me (LQ; UQ) - медіана (нижній і верхній квартилі))

\begin{tabular}{|c|c|c|c|c|c|}
\hline \multirow{2}{*}{ Дослідна група } & \multicolumn{5}{|c|}{ Термін реперфузійного періоду } \\
\hline & 3 год & 4 год & 1 доба & 7 доба & 14 доба \\
\hline \multicolumn{6}{|c|}{ Контрольна група=5,00 (4,77; 5,21) (n=6) } \\
\hline $\begin{array}{l}\text { 1-ша група } \\
\text { (ішемія-реперфуузія) }\end{array}$ & $\begin{array}{c}4,69 \\
(4,43 ; 5,18) \\
(n=6)\end{array}$ & $\begin{array}{c}4,47^{\star} \\
(4,43 ; 4,50) \\
(n=6)\end{array}$ & $\begin{array}{c}4,00 * 3 r, 4 r \\
(3,96 ; 4,08) \\
(n=6)\end{array}$ & $\begin{array}{c}4,49 * 1 A \\
(4,46 ; 4,63) \\
(n=6)\end{array}$ & $\begin{array}{c}5,24^{2 \Gamma, 1 A, 7 \AA} \\
(5,13 ; 5,26) \\
(n=6)\end{array}$ \\
\hline $\begin{array}{l}\text { 2-га група } \\
\text { (крововтрата) }\end{array}$ & $\begin{array}{c}3,32^{*} \\
(3,17 ; 3,40) \\
(n=6)\end{array}$ & $\begin{array}{c}3,02^{* 3 r} \\
(2,97 ; 3,06) \\
(n=6)\end{array}$ & $\begin{array}{c}2,61^{* 3 r, 4 r} \\
(2,56 ; 2,67) \\
(n=6)\end{array}$ & $\begin{array}{c}3,40 * 4,1 \mathrm{~A} \\
(3,34 ; 3,48) \\
(n=6)\end{array}$ & $\begin{array}{c}4,04^{* 3 г, 4 г, 1 д, 7 д} \\
(3,92 ; 4,15) \\
(n=6)\end{array}$ \\
\hline $\begin{array}{l}\text { 3-тя група } \\
\text { (ішемія-реперфузія+ } \\
\text { крововтрата) }\end{array}$ & $\begin{array}{c}2,79^{*} \\
(2,74 ; 3,03) \\
(n=6)\end{array}$ & $\begin{array}{c}2,62^{*} \\
(2,58 ; 2,71) \\
(n=6)\end{array}$ & $\begin{array}{c}2,14^{* 3 r, 4 r} \\
(2,00 ; 2,24) \\
(n=6)\end{array}$ & $\begin{array}{c}2,52 * 3,1 \mathrm{~A} \\
(2,40 ; 2,68) \\
(n=6)\end{array}$ & 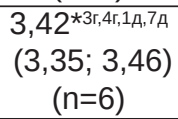 \\
\hline$p_{1-2}$ & $<0,05$ & $<0,05$ & $<0,05$ & $<0,05$ & $<0,05$ \\
\hline$p_{1-3}$ & $<0,05$ & $<0,05$ & $<0,05$ & $<0,05$ & $<0,05$ \\
\hline$p_{2-3}$ & $<0,05$ & $<0,05$ & $<0,05$ & $<0,05$ & $<0,05$ \\
\hline
\end{tabular}

всі терміни реперфузійзного періоду $(p<0,05)$. Так само у всі терміни спостереження показник виявився істотно меншим порівняно з групою, в якій моделювали саму гостру крововтрату: через 3 год - на 15,6 \%, через 4 год - на 13,3\%, через 1 добу - на 18,0 \%, через 7 діб - на 25,9\%, через 14 діб - на 15,3 \% ( $\left.p_{2-3}<0,05\right)$.

При аналізі впливу карбацетаму за умов гострої крововтрати, ускладненої ішемією-реперфузією (рис. 1, 2), було встановлено, що семиденне застосування препарату, порівняно з групою тварин без корекції, супроводжувалося суттєвим зростанням як проксимального, так і дистального транспорту натрію (відповідно, на 72,0 та 32,1 \%, p<0,05). Аналогічно карбацетам зумовлював підвищення досліджуваних показ- ників після 14 днів використання (відповідно, на 20,7 та 15,2\%, p<0,05).

Отримані результати свідчать про те, що реперфузія після двогодинної ішемії кінцівки в білих щурів супроводжувалась істотним зниженням проксимального і дистального транспорту натрію з максимумом порушень через 1 добу та нормалізацією показників через 14 діб. Враховуючи енергозалежність процесів проксимального і дистального транспорту, їх високу чутливість до забезпечення киснем, можна припустити, що токсини $з$ ішемізованої кінцівки, які 3 кровотоком надходять у нирки, здатні блокувати процеси споживання кисню епітелієм проксимальних і дистальних канальців за рахунок посилення процесів ліпідної пероксидації, про що 


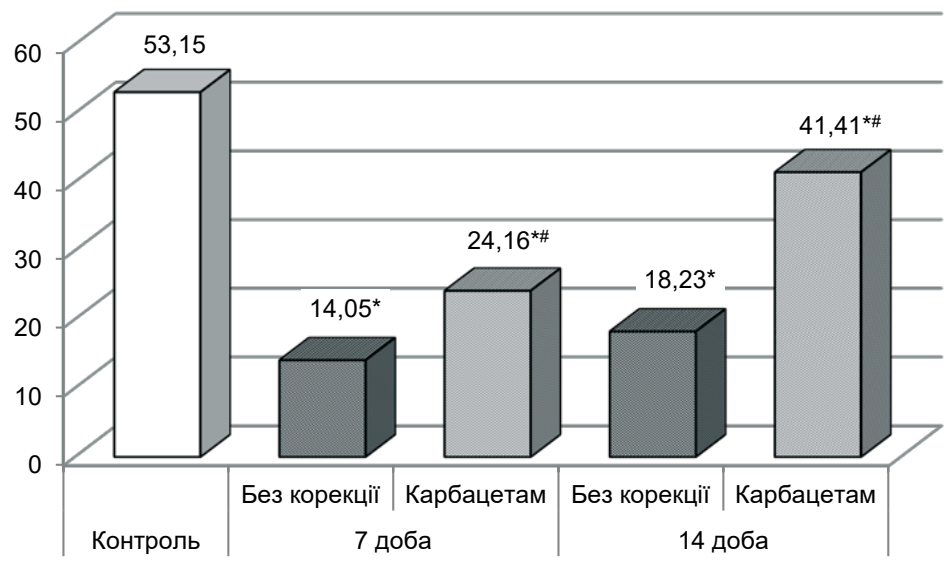

Рис. 1. Вплив карбацетаму на проксимальний транспорт натрію (мкмоль·ХВ ${ }^{-1} \cdot 100 r^{-1}$ ) після гострої крововтрати, ускладненої ішемією-реперфузією кінцівки.

Примітки. Тут і на рисунку 2:

1. * - відмінності стосовно контрольної групи статистично вірогідні $(p<0,05)$.

2. \# - відмінності стосовно групи без корекції статистично вірогідні $(p<0,05)$.

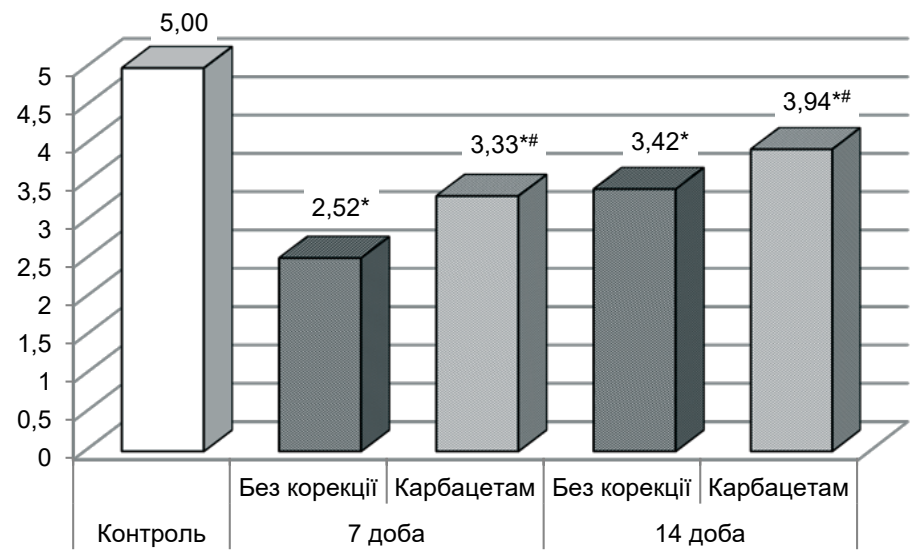

Рис. 2. Вплив карбацетаму на дистальний транспорт натрію (мкмоль·хв ${ }^{-1} \cdot 100 r^{-1}$ ) після гострої крововтрати, ускладненої ішемією-реперфузією кінцівки.

йдеться в роботах окремих авторів [9]. Гостра крововтрата, завдяки гіпоперфузії нирки, закономірно поглиблює порушення процесів проксимального і дистального транспорту натрію [12]. За умов поєднання гострої крововтрати та ішемії-реперфузії кінцівки відмічають нашарування патогенних механізмів обох видів уражень, що супроводжується більшим зниженням досліджуваних показників, особливо дистального транспорту натрію, величина якого у всі терміни реперфузійного періоду була істотно меншою, ніж в інших дослідних групах.

Отримані результати мають вагоме практичне значення, оскільки в ході надання допомоги постраждалим і пораненим націлюють на обов'язкове врахування фракту ішемії та реперфузії кінцівки, що може істотно поглибити перебіг геморагічного шоку і стимулювати розвиток органної диссрункції. Усе це потребує пошуку есективних засобів нівелювання впливу ішемії-реперфузії кінцівки за умов гострої крововтрати. Як показали результати проведених досліджень, ефективним у зменшенні порушень проксимального і дистального транспорту натрію виявився карбацетам. Його застосування у групі тварин з гострою крововтратою, ускладненою ішемією-реперфузією кінцівки, призвело до підвищення досліджуваних показників як через 7, так і через 14 діб застосування. Отже, за умов гострої крововтрати та ішемії-реперфузії кінцівки карбацетам проявляє несрропротекторну активність, що потребує подальшого доклінічного вивчення.

ВИСНОВКИ. 1. Реперфузія після двогодинної ішемії кінцівки супроводжується істотним зниженням проксимального і дистального транспорту натрію з максимумом через 1 добу реперфузійного періоду і відновленням показників до рівня контролю через 14 діб.

2. Гостра крововтрата в обсязі 20-22\% об'єму циркулюючої крові суттєво поглиблює порушення проксимального і дистального транспорту натрію у всі терміни спостережен- 
ня, не повертаючись до рівня контролю через 14 діб.

3. Ускладнення гострої крововтрати двогодинною ішемією і реперсузією кінцівки викликає більше зниження величини проксимального (через 4 год та 7 діб) і дистального транспорту натрію (у всі терміни репердузійного періоду) порівняно з дослідною групою, в якій моделювали саму крововтрату. Застосування за цих умов карбацетаму в дозі 5 мг·кг-1 супроводжується підвищенням досліджуваних показників як після семиденного, так і після чотирнадцятиденного використання, не досягаючи рівня контрольної групи.

Перспективи подальших досліджень. У перспективі доцільно поглибити дослідження стосовно вивчення механізмів нефропротекторної активності карбацетаму за умов гострої крововтрати, ускладненої ішемією-реперфузією кінцівки.

\section{СПИСОК ЛІТЕРАТУРИ}

1. Global differences in causes, management, and survival after severe trauma: the recombinant activated factor VII phase 3 trauma trial / M. C. Christensen, M. Parr, B. J. Tortella [et al.] // Journal of Trauma. - 2010. 69 (2). - P. 344-352.

2. Do we really rely on fast for decision making in the management blunt abdominal trauma? / J. Carter, M. Falco, M. Chopko [et al.] // Injury. - 2015. - 46, No. 3. P. 817-821.

3. Efficacy of prehospital application of tourniquets and hemostatic dressings to control traumatic external hemorrhage. - Access mode : https://www.ems.gov/pdf/ research/Studies-and-Reports.pdf

4. Limb complications following pre-hospital tourniquet use / J. C. Clasper, K. V. Brown, P. Hill // J R Army Med. Corps. - 2009. - 155 (3). - P. 200-202.

5. Телевяк А. Т. Динаміка показників перекисного окислення ліпідів та антиоксидантного захисту в м'язовій тканині задніх кінцівок щурів при розвитку ішемічно-реперфузійного синдрому (експериментальне дослідження) / А. Т. Телевяк // Здобутки клініч. і експерим. медицини. - 2018. - № 3 (35). - С. 132-139.

6 . Volotovska N. V. Changes in the glutathione system's activity of internal organs in the first hours of experimental limb ischemia-reperfusion syndrome, combined with blood loss and mechanical injury / N. V. Volotovska, T. C. Nhokwara, I. V. Zhulkevych // Здобутки клінічної і експериментальної медицини. - 2019. - № 1. C. 23-27. DOI 10.11603/1811-2471.2019.v0.i1.10043

\section{REFERENCES}

1. Christensen, M.C., Parr, M., Tortella, B.J., Malmgren, J., Morris, S., Rice, T., \& Holcomb, J.B. (2010). Global differences in causes, management, and survival after severe trauma: the recombinant activated factor VII phase 3 trauma trial. Journal of Trauma, 69 (2), 344-352.

2. Carter, J.W., Falco, M.H., Chopko, M.S., Flynn, W.J.Jr., Wiles lii, C.E., \& Guo, W.A. (2015). Do we really rely on fast for decision-making in the management of blunt abdominal trauma? Injury, 46 (5), 817-821.
7. Wright G. Would civilian pre-hospital emergency care provision include tourniquets for the management of uncontrolled traumatic haemorrhage? / G. Wright, V. S. Mcdonald, V. G. Smith // Australasian Journal of Paramedicine. - 2015. - 12 (4). - P. 1-5.

8. Кузьмінський І. В. Особливості жовчовидільної фрункції печінки в умовах ішемічно-реперфузійного синдрому кінцівок, закритої травми органів черевної порожнини, ускладненої масивною крововтратою / І. В. Кузьмінський // Актуальні проблеми транспортної медицини. - 2018. - № 4 (54). - С. 148-158.

9. Цимбалюк Г. Ю. Стан добового діурезу нирок в умовах ішемічно-реперфузійного синдрому кінцівок, травми органів черевної порожнини, ускладненої гіповолемічним шоком, та їх поєднання у ранньому періоді травматичної хвороби / Г. Ю. Цимбалюк // Здобутки клініч. і експерим. медицини. - 2018. № 3 (35). - С. 163-169.

10. Козак Д. В. Вплив карбацетаму на антиоксидантний-прооксидантний баланс тканини серця, легень і печінки в динаміці політравми / Д. В. Козак // Шпитальна хірургія. - 2014. - № 1 (65). - С. 40-42.

11. Роговий Ю. Є. Патосрізіологія гепаторенального синдрому на поліуричній стадії сулемової нефропатії / Ю. Є. Роговий. - Чернівці : Місто, 2012. - 200 с.

12. Ковальов В. В. Динаміка функціонального стану нирок у ранній період після нанесення скелетної травми різної тяжкості, ускладненої крововтратою / В. В. Ковальов, Д. В. Попович // Вісн. наук. дослідж. 2018. - № 4. - C. 184-189.

3. Efficacy of prehospital application of tourniquets and hemostatic dressings to control traumatic external hemorrhage. Retrieved from: https://www.ems.gov/pdf/ research/Studies-and-Reports.pdf

4. Clasper, J.C., Brown, K.V., \& Hill, P. (2009). Limb complications following pre-hospital tourniquet use. $J R$ Army Med. Corps., 155 (3), 200-202.

5. Televiak, A.T. (2018). Dynamika pokaznykiv perekysnoho okyslennia lipidiv ta antyoksydantnoho zakhystu v miazovii tkanyni zadnikh kintsivok shchuriv 
pry rozvytku ishemichno-reperfuziinoho syndromu (eksperymentalne doslidzhennia) [Dynamics of lipid peroxidation and antioxidant protection in rat muscle of the hind limbs in the development of ischemic-reperfusion syndrome (experimental study)]. Zdobutky klinichnoi $i$ eksperymentalnoi medytsyny-Achievements of Clinical and Experimental Medicine, 3 (35), 132-139 [in Ukrainian].

6. Volotovska, N.V., Nhokwara, T.C., \& Zhulkevych, I.V. (2019). Changes in the glutathione system's activity of internal organs in the first hours of experimental limb ischemia-reperfusion syndrome, combined with blood loss and mechanical injury. Zdobutky klinichnoi $i$ eksperymentalnoi medytsyny-Achievements of Clinical and Experimental Medicine, 1, 23-27. DOI 10.11603/18112471.2019.v0.i1.10043

7. Wright, G., Mcdonald, V.S., \& Smith, V.G. (2015). Would civilian pre-hospital emergency care provision include tourniquets for the management of uncontrolled traumatic haemorrhage? Australasian Journal of Paramedicine, 12 (4), 1-5.

8. Kuzminskyi, I.V. (2018). Osoblyvosti zhovchovydilnoi funktsii pechinky $v$ umovakh ishemichno-reperfuziinoho syndromu kintsivok, zakrytoi travmy orhaniv cherevnoi porozhnyny, uskladnenoi masyvnoiu krovovtratoiu [Features of biliary function of the liver in conditions of ischemic-reperfusion syndrome of the extremities, closed trauma of the abdominal organs, complicated by massive blood loss]. Aktualni problemy transportnoi medytsyny - Actual Problems of Transport Medicine, 4 (54), 148-158 [in Ukrainian].
9. Tsymbaliuk, H.Yu. (2018). Stan dobovoho diurezu nyrok $v$ umovakh ishemichno-reperfuziinoho syndromu kintsivok. Travmy orhaniv cherevnoi porozhnyny, uskladnenoi hipovolemichnym shokom, ta yikh poiednannia u rannomu periodi travmatychnoi khvoroby [Condition of diurnal diuresis of the kidneys in conditions of ischemicreperfusion limb syndrome. Injuries of abdominal organs complicated by hypovolemic shock and their combination in the early period of traumatic disease]. Zdobutky klinichnoi i eksperymentalnoi medytsyny-Achievements of Clinical and Experimental Medicine, 3 (35), 163-169 [in Ukrainian].

10. Kozak, D.V. (2014). Vplyv karbatsetamu na antyoksydantnyi-prooksydantnyi balans tkanyny sertsia, lehen i pechinky $v$ dynamitsi politravmy [Influence of carbacetam on antioxidant-prooxidant balance of tissue of heart, lungs and liver in the dynamics of polytrauma]. Shpytalna khirurhiia - Hospital Surgery, 1 (65), 40-42 [in Ukrainian].

11. Rohovyi, Yu.Ye. (2012). Patofiziolohiia hepatorenalnoho syndromu na poliurychnii stadii sulemovoi nefropatii [Pathophysiology of hepatorenal syndrome at the polyuric stage of sulemic nephropathy]. Chernivtsi: Misto [in Ukrainian].

12. Kovalov, V.V., \& Popovych, D.V. (2018). Dynamika funktsionalnoho stanu nyrok u rannii period pislia nanesennia skeletnoii travmy riznoi tiazhkosti, uskladnenoi krovovtratoiu [Dynamics of functional condition of kidneys in the early period after skeletal injury of different severe complicated by blood loss]. Visnyk naukovykh doslidzhen - Bulletin Scientific Research, 4, 184-189 [in Ukrainian].

\section{ОСОБЕННОСТИ ПРОКСИМАЛЬНОГО И ДИСТАЛЬНОГО ТРАНСПОРТА НАТРИЯ ПРИ ОСТРОЙ КРОВОПОТЕРЕ, ОСЛОЖНЕННОЙ ИШЕМИЕЙ-РЕПЕРФУЗИЕЙ КОНЕЧНОСТИ, И ИХ КОРРЕКЦИЯ В ЭКСПЕРИМЕНТЕ}

Резюме

Вступление. Самым эфрфективным способом остановки массивного наружного кровотечения признано наложение жгута. Полное обескровливание конечности в течение 2 ч может вызвать повреждение нервов и сосудов под жгутом, мионекроз, рабдомиолиз, тромбоз глубоких вен. Однако недостаточно изучено роль ишемии-реперфузии конечности в патогенезе нарушений ионорегулирующей фрункции почек в условиях острой кровопотери. Нет данных об эфрфективности их коррекции карбацетамом.

Цель исследования - выяснить особенности почечного транспорта натрия в ранний период после нанесения скелетной травмы различной тяжести, осложненной кровопотерей, и эфффективность коррекции выявленных нарушений карбацетамом.

Методы исследования. Эксперименты выполнены на 108-ми нелинейных крысах-самцах массой 160-180 г. В 1-й исследовательской группе моделировали двухчасовую ишемию конечности с последующей реперфузией, во 2-й - острую кровопотерю в объеме 20-22 \% объема циркулирующей крови, в 3-й - эти повреждения сочетали, в 4-й - животным с острой кровопотерей и ишемией-реперфузией конечности внутрибрюшно вводили карбацетам в дозе 5 мг/ке. Через 1 и 2 ч, а также через 1, 7 и 14 суток у крыс исследовательских групп определяли фрункциональное состояние почек методом водной нагрузки. Животных контрольной группы вводили в наркоз и брали для исследований через 1 ч. Определяли диурез и 
концентрацию ионов натрия в моче и сыворотке крови. Рассчитывали проксимальный и дистальный транспорт натрия.

Результаты и обсуждение. Реперфузия после двухчасовой ишемии конечности в белых крыс сопровождалась существенным снижением проксимального и дистального транспорта натрия с максимумом нарушений через 1 сутки и нормализацией показателей через 14 суток. Острая кровопотеря существенно углубляла нарушение процессов проксимального и дистального транспорта натрия. Сочетание острой кровопотери и ишемии-реперфузии конечности сопровождалось большим снижением показателей. Использование карбацетама привело к улучшению исследуемых показателей через 7 и 14 суток применения, которые не достигали уровня контрольной группы.

Выводы. Осложнение острой кровопотери двухчасовой ишемией и реперфузией конечности вызывает большее снижение величины проксимального и дистального транспорта натрия по сравнению с другими исследовательскими группами. Применение в этих условиях карбацетама сопровождается нефропротекторным эфрфректом.

КЛЮЧЕВЫЕ СЛОВА: кровопотеря; ишемия-реперфузия конечности; почка; проксимальный и дистальный транспорт натрия.

V. V. Shatsky

I. HORBACHEVSKY TERNOPIL NATIONAL MEDICAL UNIVERSITY

\section{FEATURES OF PROXIMAL AND DISTAL TRANSPORT OF SODIUM IN ACUTE BLOOD LOSS, COMPLICATED BY ISCHEMIA-REPERFUSION OF EXTREMITY, AND THEIR CORRECTION IN THE EXPERIMENT}

\section{Summary}

Introduction. The most effective way to stop massive external bleeding is the application of a tourniquet. Complete bleeding of the limb within 2 hours can cause damage to nerves and blood vessels under the tourniquet, myonecrosis, rhabdomyolysis, deep vein thrombosis. However, the role of limb ischemia-reperfusion in the pathogenesis of impaired renal function in acute blood loss has not been adequately studied. There is no data on the effectiveness of their correction with carbacetam.

The aim of the study - to find out the features of the renal transport of sodium ions in the early period after applying a skeletal injury of varying severity, complicated by blood loss and the effectiveness of the correction of the revealed violations with carbacetam.

Research Methods. The experiments were performed on 108 non-linear male rats weighing 160-180 g. In the research group 1, two-hour limb ischemia was simulated followed by reperfusion, in group 2 - acute blood loss in the amount of 20-22 \% of the circulating blood volume, in group 3 - these injuries were combined, in group 4 animals with acute blood loss and limb ischemia-reperfusion was administered intraperitoneally at a dose of $5 \mathrm{mg} / \mathrm{kg}$. After 1 and 2 hours, as well as after 1, 7 and 14 days in rats of the research groups, the functional state of the kidneys was determined by the method of water loading. The animals of the control group were injected with anesthesia and taken for research after 1 hours. The urine output and concentration of sodium ions in urine and blood serum were determined. The proximal and distal sodium transport was calculated.

Results and Discussion. Reperfusion after two-hour limb ischemia in white rats was accompanied by a significant decrease in proximal and distal sodium transport with a maximum of disturbances after 1 day and normalization after 14 days. Acute blood loss significantly exacerbated the violation of the proximal and distal sodium transport processes. The combination of acute blood loss and limb ischemia-reperfusion was accompanied by a large decrease of indicators. The use of carbacetam led to an improvement in the studied parameters after 7 and 14 days of use, which did not reach the level of the control group.

Conclusions. The complication of acute blood loss by two-hour ischemia and reperfusion of the limb causes a greater decrease in the proximal and distal sodium transport compared to other research groups. The use of carbacetam under these conditions is accompanied by a nephroprotective effect.

KEY WORDS: blood loss; limb ischemia-reperfusion; kidney; proximal and distal sodium transport.

Отримано 29.10.19

Адреса для листування: В. В. Шацький, Тернопільський національний медичний університет імені І. Я. Горбачевського мОЗ України, майдан Волі, 1, Тернопіль, 46001, Україна, e-mail: viktor@tdmu.edu.ua. 